\title{
Promoting Responsible Tourism by Exploring Sea- voyage Migration Narratives through ELF: An Experiential-linguistic Approach to Multicultural Community Integration
}

\author{
Maria Grazia Guido ${ }^{*} *$ (D), Pietro Luigi Iaia ${ }^{a} \dagger\left(\mathbb{D}\right.$, Lucia Errico ${ }^{a}$ (D) \\ ${ }^{a}$ University of Salento, Piazza A. Rizzo, Lecce, 73100, Italy
}

Received 20 January 2019 | Received in revised form 18 June 2019 | Accepted 04 July 2019

\begin{abstract}
APA Citation:
Guido, M. G. \& Iaia, P. L. \& Errico, L. (2019). Promoting responsible tourism by exploring sea-voyage migration narratives through ELF: An experiential-linguistic approach to multicultural community integration. Eurasian Journal of Applied Linguistics, 5(2), 219-238. Doi: 10.32601/ejal.599240
\end{abstract}

\begin{abstract}
This paper reports on a research project in Responsible Tourism (Prayag, Hosany, \& Odeh, 2013) carried out at the University of Salento in collaboration with the local administrations of some seaside resorts in Southern Italy affected by migrants' massive arrivals. This project, which involves tourists, migrants, university students in intercultural mediation and local communities, applies a model of ExperientialLinguistics (Lakoff \& Johnson, 1999) to a multimodal Ethnopoetic analysis (Hymes, 2003; Kress, 2009) of (a) non-Western migrants' traumatic accounts of journeys across the sea, reported in their own ELF variations (Guido, 2008, 2018), (b) Western epic narratives of Mediterranean dramatic voyages rendered from Ancient Greek and Latin into modern ELF variations, and (c) multimodal representations of the ethnopoetic rhythms of such ancient and modern sea-journey narratives through the production of a promotional video. The aim is to highlight the experiential common roots shared by classical-epic and contemporary migration narratives. Three main research phases will be explored, which are characterised by pedagogical activities meant to foster an active, multicultural community integration, as well as a view of tourism as an inclusive social experience.
\end{abstract}

(C) 2019 EJAL \& the Authors. Published by Eurasian Journal of Applied Linguistics (EJAL). This is an open-access article distributed under the terms and conditions of the Creative Commons Attribution license (CC BY-NC-ND) (http://creativecommons.org/licenses/by-nc-nd/4.0/).

Keywords: English as a Lingua Franca; Responsible Tourism; migrants' ELF sea-journey narratives; ELF translation of Ancient-Greek and Latin journey narratives; multimodal ethnopoetic analysis

\footnotetext{
* Corresponding author.

E-mail address: mariagrazia.guido@unisalento.it

${ }^{\dagger}$ E-mail address: pietroluigi.iaia@unisalento.it

‡E-mail address: luciaerrico3@gmail.com
} 


\section{Introduction}

This paper reports on a research project in Responsible Tourism (Hosany \& Prayag, 2011; Ma, Gao, Scott, \& Ding, 2013; Prayag, Hosany, \& Odeh, 2013; Lin, Kerstetter, Nawijin, \& Mitas, 2014)§ focused on multicultural integration carried out at the University of Salento in collaboration with the local administrations of some seaside resorts in Southern Italy affected by migrants' massive arrivals. This project, which aimed to involve tourists, migrants, local communities, and university students of intercultural mediation as research participants selected on a voluntary basis, applies a model of Experiential-Linguistics (Sweetser, 1990; Langacker, 1991; Lakoff \& Johnson, 1999) to a multimodal Ethnopoetic analysis (Hymes, 2003; Kress, 2009) of non-Western migrants' traumatic accounts of sea-journeys reported in their own variations of English as a Lingua Franca (ELF) as well as of Western epic narratives of Mediterranean dramatic voyages rendered from Ancient Greek and Latin into modern ELF variations. This parallel analysis of ancient and modern sea-voyage narratives rendered into ELF was meant to directly involve the groups of participants taking part in this project with the purpose of ultimately making both Western tourists/local communities and non-Western migrantsliving together in the same seaside resorts in Southern Italycome to discover together their common identity roots' as seafaring voyagers.

This research starts from the assumption that the expression "ELF variations" is to be referred to the variants of non-native/nativized English used as a 'lingua franca' in contexts of intercultural communication and characterized by semantic, syntactic and pragmatic transfers from the speakers' native linguacultural background (Guido, $2008,2018)$. On such grounds, in the context of this specific project, the ELF variations used by migrants in reporting their sea-voyage narratives were reformulated into a 'hybrid ELF variant' aimed at rendering both modern and ancient sea-voyage narratives accessible to all the interacting groups of tourists, migrants and local communities participating in this research in Responsible Tourism. Indeed, a number of pedagogic activities implemented in the context of this research were precisely devised to raise the participants' awareness of the shared sea-voyage experience reported in ancient and contemporary migration narratives. This was expected to foster an active, multicultural community integration, as well as a view of tourism as an inclusive social experience - which is the ultimate objective of this research project in Responsible Tourism enquiring into the effects of emotions associated with the perception of holidays as an individual and socio-cultural growth. These effects are investigated here in relation to the seaside resorts of the Salento area, whose reputation of hospitable places characterized by a hybridization of languages and cultures is strictly associated with their geographical position on the

The aim of Responsible Tourism is to promote tourists' experience of socio-culturally disadvantaged contexts

It "endeavours to make tourism an inclusive social experience and to ensure that there is access for all, in particular vulnerable and disadvantaged communities and individuals", and "makes positive contributions to the conservation of natural and cultural heritage and to the maintenance of the world's diversity."

(http://responsibletourismpartnership.org/). 
Southern Mediterranean coasts of Italy. Ethnographic data collected in these places (Guido, 2016) have revealed that misunderstandings between tourists and migrants are to be ascribed not only to structural and pragmatic divergences of their respective native languages transferred into their ELF variations in contact, but also to the two groups' dissimilar experiential 'schemata' - namely, the linguacultural background knowledge that the two groups share with their respective primary or native speech communities (Carrell, 1983) - which, in the case in point, also involve the two groups' different 'sea-voyage schemata' reflecting their diverging experiences of the journey towards the destination place. Previous research (Guido, Iaia, \& Errico, 2018) has indeed revealed that the divergence between tourists' and migrants' schemata is rooted in their respective perception of the seaside resorts they live in as the representation of the 'Utopia vs. Dystopia (anti-Utopia)' archetype (Guido, Errico, Iaia, \& Amatulli, 2016). This oxymoronic archetype is in fact intrinsic in the term 'Utopia', to be related to its two opposite Ancient-Greek etymological sources: eu-topos ('place of good and harmony') and ou-topos ('no place', 'nowhere') - the latter often representing to the migrants' displacing experience of their landing site.

In Phase 1 of this research, the participants were asked to investigate 'experientially' the organization into spontaneous 'ethnopoetic verses' (Hymes, 2003) of a corpus of journey reports collected in reception centres for migrants, so as to become aware of their emotional structures reproducing sequences and rhythms of human feelings, actions, and reactions, which is typical of autochthonous oral narratives of past and present times (section 2). At this stage, the contact between the groups of the participants was also meant to help them develop a 'hybrid' use of ELF that, by respecting the rhythms and structures of the migrants' original journey reports narrated through their own different ELF variations, aimed at making such reports comprehensible to all the participants involved in this project so as to allow them to rediscover their common sea-journey experiential schemata and narrative structures (Guido, 2018). Such a hybrid ELF variation was then employed also in Phase 2 for the ethnopoetic translation of some extracts from Homer's Odyssey and Virgil's Aeneid (Section 3). These translations were not produced for aesthetic reasons, but in order to make all the participants in this project aware of the shared linguacultural features of the epic narratives of Mediterranean 'odysseys' belonging to the Western cultural heritage, starting from the cognitive association between the character of the 'Observer', that is, the 'voyager' in the structure of the classical Utopian genre, and the 'Traveller' as the modern 'migrant' landing in Utopia after a perilous sea-voyage. The epic sea-voyages of the classic narrative, such as Odysseus (Ulysses) and Aeneas, indeed represent cognitive archetypes which have shaped the Western travel literature over time, but which are also present in the experiential schemata of other non-Western populations. Finally, in Phase 3 the participants were guided to render ancient and modern sea-journey narratives and their experiential ethnopoetic rhythms into multimodal representations (Kress, 2009), eventually producing a promotional video with ELF subtitles (section 4). In it, Salento is connoted as the mythical Utopia welcoming voyagers with the ultimate objective of 
inducing a novel perception of Responsible Tourism as an intercultural and ethical experience.

\section{Phase 1: Ethnopoetic analysis of migrants' sea-voyage narratives}

In Phase 1, the participants were involved in a pedagogical activity concerning the ethnopoetic analysis of an extract from a corpus of African migrants' oral sea-voyage narratives. In the selected accounts, speakers tend to personify violent natural elements and inanimate objects (respectively, stormy sea and giant waves, and the ship), which therefore become the Subjects of ergative clauses [OVS], as if they were animate Agents with their own autonomous energy (Talmy, 1988). This can be explained by the fact that such ergative clausal constructions are a typical feature of Proto-Indo-European and Proto-Afro-Asiatic languages spoken by earliest human beings living in a natural environment that they experienced as dangerous, thus personifying its inanimate components as conscious hostile Agents, collocating them in Subject position within the clauses of their oral narratives. Today, such ancient ergative constructions can be found in many contemporary African languages (Greenberg, 1963; Buth, 1981; Anderson, 1988; Heine \& Nurse, 2000) which entail that they are automatically transferred into the structures of the ELF variations spoken by African migrants (Guido, 2008, 2012). The investigation of these modern African tales in the first part of this project is meant to make participants acquainted with the ergative structures of 'non-Western' migrants' sea-voyage narrations. An initial strategy adopted to make the Western participants (tourists and local communities) familiarize with the ergative structures of African migrants' oral journey narratives was to make reference to their shared literary knowledge and to their 'cultural memory', since the Ergativity characterizing the earliest oral narratives was also employed in a number of Western literary reconstructions of ancient forms of folktales. For these reasons, the participants were presented with the 'STORM-BLAST' scene from The Rime of the Ancient Mariner - S.T. Coleridge's poetic revisitation of ancient oral narratives. The following extract allowed migrants, tourists and local communities as participants to reflect upon the stylistic strategy of putting in the foreground "the ship" (the "sailors" represented in the poem identify themselves with) and the "STORM-BLAST" (whose ferocity is emphasized by the capital letters), which become 'ergative actors' in subject position within clauses, violently fighting one against the other (cf. Guido, 1999):

And now the STORM-BLAST came, and he

Was tyrannous and strong;

He struck with his o'ertaking wings,

And chased us south along. 
With sloping masts and dipping prow,

As who pursued with yell and blow

Still treads the shadow of his foe,

And forward bends his head,

The ship drove fast, loud roared the blast,

And southward aye we fled.

(Lines 41-50 - italics added to emphasize personified ergative actors)

This preliminary reading was expected to trigger the participants' experiential readiness to personally and emotionally identify themselves with the ergative subjects in the migrants' sea-voyage narratives - like the one reproduced below, regarding a Nigerian migrant's oral journey report in Nigerian Pidgin English (NPE) - a nativized variety of English which in Italy is normally perceived as a non-native ELF variation used by Nigerian migrants (Guido, 2008). The migrant's oral report is patterned into spontaneous 'ethnopoetic verses' (Hymes, 2003) marked by a specific rhythm that stresses the emotions associated with the narrated story as well as by ergative personifications of natural elements collocated in force-dynamic subject positions (i.e., as if they were endowed with their own autonomous and intentional movement). In this way, the migrants represented in this report - who identify themselves with the 'ship' carrying them - desperately fight against the natural elements personified as hostile animate entities and, as such, foregrounded as the 'themes' of the clauses (cf. Halliday 1994). What follows is the ethnopoetic transcript of the Nigerian migrant's narrative. After reporting its source (NPE variant) and Standard-English versions (between square brackets), the migrant's narration was reformulated into a specific ELF variation aimed at being accessible to all the participants in the project and, at the same time, meant to reproduce the rhythmical and syntactic patterns of the source text. The ultimate objective of such a reformulation was to reproduce the emotional tone of the original account of events even though the representative syntactic structures of this variety (e.g., pre-verbal tense/aspect markers "bin", "de", "don"; the plural marker "dem", etc.) were omitted insofar as they could be obscure to tourists and local inhabitants of the host resorts as participants in this activity. ${ }^{* *}$ 


\section{Ethnopoetic transcript:}

won old ship bin bo::ard os many many >na wahala every wie o< [an old ship boarded us, too many, affliction was everywhere]

An old ship did board us many many, the affliction everywhere, oh

$=$ di $\underline{\text { deck }}$ so:: so::: bin pack (.) di hold so so bin $\underline{\text { cra::m }}$ [the deck was so packed and the hold so crammed]

The deck so so much packed, the hold so so much crammed

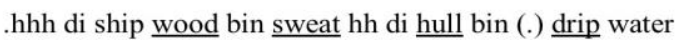

[the ship wood sweated, the hull leaked water]

The ship wood did sweat, the hull did drip water

hh after won day journey

[after one day journey]

After one day journey

di $\underline{\text { ship }}$ bin $\underline{\text { struggle }}$ struggle against di se:::a (.) .hh-heavy won night

[the ship struggled against the rough sea in the night]

The ship did struggle struggle against the sea, heavy one night

\# Conversation symbols: [] $\rightarrow$ overlapping speech; underlining $\rightarrow$ emphasis;

$\circ \circ$ quieter speech; (.) $\rightarrow$ micropause; (..) $\rightarrow$ pause; $:: \rightarrow$ elongation of prior sound; hhh $\rightarrow$ breathing out; .hhh $\rightarrow$ breathing in; $><\rightarrow$ speed-up talk; $=\rightarrow$ latching. 
(.) hhh di wave dem bin de ri::se (.) like tower (.) na cold cold o o [the waves were rising like towers and they were so cold!]

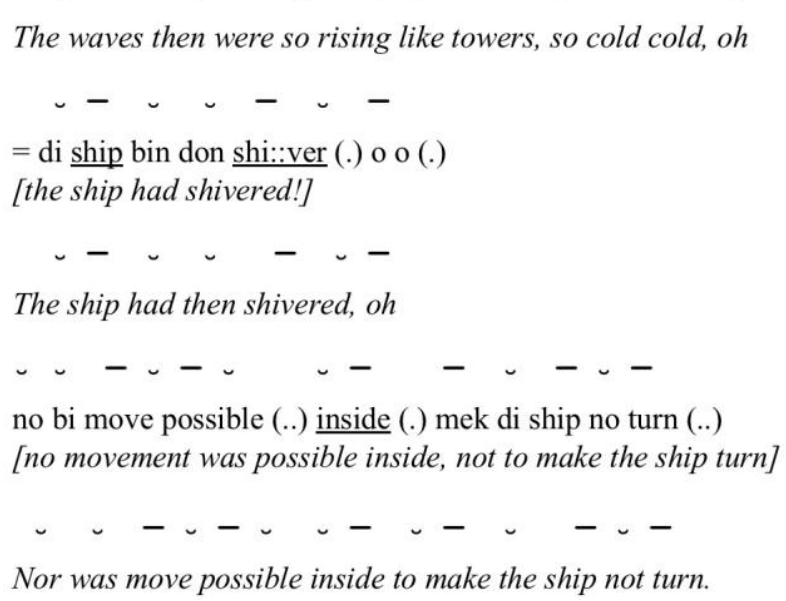

At the time of examining and interpreting the ergative clauses of the sea-voyage narrative above, the participants were made aware of the migrants' process of embodiment of the force-dynamic subject of the "ship" or, metonymically, of some of its parts. The emphasis, in the clausal structure, is on the ergative-subject clausal collocation of the "old ship" that carries too many migrants, triggering negative emotional states in them, as suggested by the Igbo term wahala, a 'substratum loanword' (Eze, 1998) for the 'affliction' that is perceived 'everywhere' on the ship. This feeling of anguish is stressed by the repetition of the emphatic phoneme /o/, an Igbo/Yoruba emotional interjection. Also word reduplication works in NPE as an 'emotional intensifier'. This 'substratum-loan structure' which is typical of Nigerian indigenous languages is used to report on the crowds of migrants on board ("many many", "so so") and the ship's perilous fight against the rough sea ("struggle struggle"). At the same time, reduplication speeds the pace of the ethnopoetic verses, thus reproducing the sound and the rhythm of the frantic throbbing of the frightened migrants' heartbeat, which can be inferred from the interruption of the regular iambic rhythm and the insertion of more stressed syllables falling on the repeated words. The series of part-of-the-ship ergative personifications by means of a metonymic 'dissection' of the vessel into its animate parts, then, embodies the migrants' disquieting feeling at realizing that they were disregarding the actual capacity of the overcrowded old ship carrying them. The ergative representation of this dramatic moment is conveyed by the intransitive use of transitive verbs - e.g., the ship-deck that 'packed', the 'hold' that "so so" 'crammed' with migrants overlooking the evidence that the "ship wood" 'sweated', and the hull 'dripped water'. This is a characteristic of 
the original NPE report that is preserved in its ELF version ("The deck so so much packed, the hold so so much crammed").

The migrants' collective identification with the ship (to which they transfer their own 'shivering' for cold and panic) increases the emotional intensity of their narration of the 'epic' battle against the rough sea and its giant waves. In such a dangerous moment, the source NPE version and its ELF reformulation are not characterized by a metrical regularity. At first an anapest is identified, followed by two stresses on the reduplicated word "many", which emphasizes the migrants' deep sense of despair conveyed by the automatic switching to the native Igbo term wahala:

won old ship bin bo::ard os many many

The anapest suddenly turns into the regular iambic rhythm describing the suffering of the parts of the vessel to be again disrupted by the more rapid pace of the anapest in the next line. The shift from the initial iambus to the anapest, which can be noticed throughout the whole narrative, reflects the instability of the migrants' anguished emotions, reproducing the pace of their breath and heartbeat as they narrate their sea-voyage. Only once is an initial trochee introduced in a shorter line marking the sudden passing of the time:

.hh after won day journey

Thanks to the transformation of the NPE pre-verbal past-tense marker "bin" into the past-simple auxiliary "did" in an inverted position within an affirmative clause, the same rhythmical effect of the original narrative is retained in the ELF version, adding emotional emphasis to the narration:

di ship bin struggle struggle against di se:.::

The ship did struggle struggle against the sea

At the end of Phase 1, the participants claimed that they acquired a novel perception of the ergative constructions and rhythms of the migrants' sea-voyage accounts. Thanks to this interpretation, they were ready to access the second phase of the project, which focused on the investigation of classical epic narratives of the ancient Greek and Latin tradition. Indeed, such ancient narrative texts report the earliest oral journey stories of humans fighting against destructive natural elements and, more importantly, share the rhythmical structures of the migrants' oral reports 
under analysis. For these reasons, a selected corpus of ancient epic narratives was retextualized by means of a hybrid ELF variation - like the one employed in the previous reformulation of the migrant's report - aimed to produce versions that could be both accessible to non-native speakers and respectful of the original metaphors and rhythms. These translations (which are reproduced in the following section) were hence presented to the participants as text-types that can help migrants familiarize with analogous sea-voyage narratives of the Western cultural heritage.

\section{Phase 2: Ethnopoetic analysis and ELF translation of ancient-Greek and Latin sea-voyage narratives}

The ELF translations of epic sea-voyage narratives $\$$ were primarily intended to $(a)$ encourage Western tourists to revive their 'archetypal schemata' as seafaring voyagers who, in a far past, struggled against the violence of natural elements; and (b) making such 'Western schemata' known to non-Western migrants that share the extreme emotional experiences of dangerously crossing the Mediterranean sea to get to Italy. Such re-textualizations were produced by means of an ELF variation that was specifically selected so as to make classical sea-voyage narratives accessible to every group of participants - i.e., students, migrants, tourists and local communities notwithstanding their being native or non-native speakers of English. Furthermore, such a variation was supposed to adhere to the original ethnopoetic verses and ergative representations of fierce natural elements as well as of the rhythms of the voyagers' emotions triggered by their description. Finally, these ELF renderings of Classical Greek and Latin languages (which were themselves 'lingua francas' of the past) were stylistically devised to restore the ethnopoetic origins of epic narratives as oral reports of frightening sea-voyages, thus identifying equivalent ELF structures by which modern migrants would convey their own native oral accounts of dreadful journey experiences (in the case in point, the ergative structures in the oral journey reports by African migrants). At this stage, a comparative ethnopoetic analysis was therefore carried out between the original extracts drawn from Book XII of Homer's Odyssey and Book III of Virgil's Aeneid, and their translation into ELF.

In the classical literature, from Homer to Eratosthenes, seafarers are often haunted heroes trying to go back to their Utopian home country by sea. In Homeric poetry, Odysseus runs across obstacles along the Western Mediterranean routes, and indeed the aim of this analysis was also to enquire into the representation of the sea as a symbol of the limit - i.e., a limen between life and death (Mondarini, 2005). Odyssey's Book XII narrates the last three adventures of Odysseus' nostos to Ithaca, all introduced by Circe: two of them - the episodes of the Sirens and of Scylla and Charybdis - represent a small section (respectively 142-200 verses and 201-259 verses), whereas the third episode in Trinacria, is the longest (304-453) one. The last accident in the sequence of events is the storm that wrecks Odysseus' ship, kills his companions and drags him towards Calypso's island, which is the end of his journey. 
These episodes reveal Odysseus' different perceptions of the sea, awakening the feelings of bewilderment and dismay, awe and pity in him, as evident in the first extract that is going to be examined (Od. 12, 403-421), which reports Odysseus' and his companions' arrival to the island of the sun-god, Helios Hyperion, after crossing Scylla and Charybdis. Its reformulation contains an ELF variation which renders the original hexameter into an iambic rhythm that comes to be suddenly disrupted as the seafarers' emotions become more intense. The episode, in fact, is characterized by dystopian elements when the tempest arises as soon as Odysseus and his comrades leave the island after having eaten Helios' sacred cows. In the original Ancient-Greek verses, the personifications of natural elements and inanimate objects (i.e., the god Zeus, son of Cronus; the storm; the lightning; the waves; and the ship) are all represented as animate agents causing the tragic events, or being affected by them. As such, they are in an ergative subject position within the clauses, which may show evidence of the possible Proto-Indo-European roots of such oral sea-voyage narratives belonging to the Western classical literary heritage:

Odyssey, 12: verses 403-408/415-420 and their ethnopoetic ELF translation:

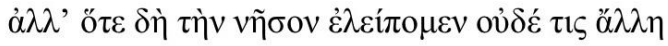

As soon as we were well far from the island

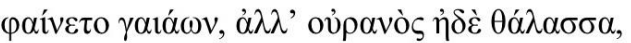

and no other land appeared, and only sky and sea were round our way

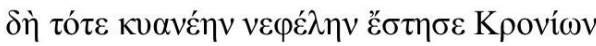

then really the son of Cronus

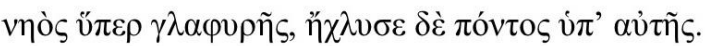

raised a purple billow above our ship and waters clouded over. 


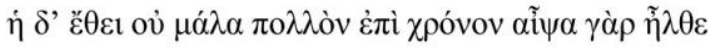

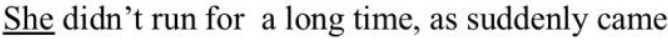

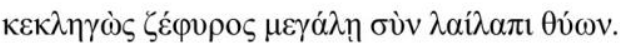

the shouting West Wind, whirling furiously. [...]

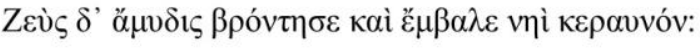

Then Zeus let fly with his thunderbolts,

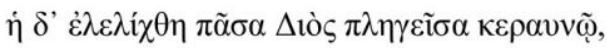

and the ship went round and round,

$\dot{\varepsilon} v \delta \dot{\varepsilon} \theta \varepsilon \varepsilon i ́ o v \pi \lambda \tilde{\eta} \tau o$,

and was filled with fire as the lightning struck it.

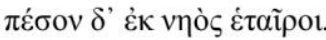

The men all fell into the sea.

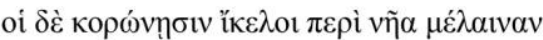

Looking like so many sea-gulls about the black ship,

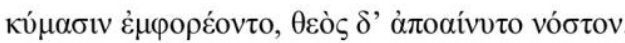

they were dragged on the foaming billows: and the God took away

their return. 
The sea-voyage report includes the characteristic features of the dystopian 'stormy scene', with the disquieting perception of the sea as a death omen (cf. De Jong, 2001). In the verses above, the metrical scanning of the hexameter emphasizes the emotional strength of the narrated events by becoming faster, which is rendered into the ELF translation by moving from an initial regular iambic rhythm:

As soon as we were well far from the island

to the unexpected introduction of a trochee stressing the first monosyllabic words to mark the start of an unexpected frightening event and to reproduce the fast pulse of the terrified sailors' thumping hearts:

raised a purple billow above our ship

to the assonance in a sequence of stressed monosyllabic words:

the shouting West Wind, whirling furiously

right up until the anapest in two consecutive lines, beginning with the conjunction "and" speeding the pace even more and emphasizing the seafarers' rising agony at realizing an impending tragic event:

and the ship went round and round

and was filled with fire

In the original ethnopoetic lines of this extract, the increasing speed of the narrative pace of the hexameter imitates the seafarers' sense of impending threat, which also materializes through dreadful natural phenomena, such as foaming waves and smoke. The sea is represented as a dark surface, whereas Odysseus' companions

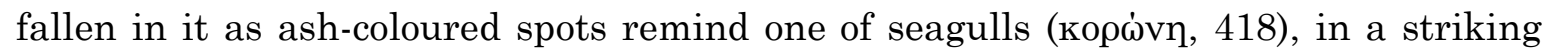
tonal contrast between light and dark. The description of the scene is organized spatially and the fierce tempest is represented in all its phases: its approach (405406); the wind rising (408); the waves breaking on the ship (417); the stillness following the storm (426-428).

The focus is on the fury of the wind $(409 ; 425)$ and of the storm wrecking the ship with shocking violence (420-425), as well as on the tempest, which also represents 
Zeus' fury against Odysseus and his sailors. The ethnopoetic rhythm of both the original and translated verses induces in listeners the sensation of nature as a cruel agent trying to destroy the human beings at its mercy (Moulinier, 1958, p. 101). Zeus himself is an ergative personification of "the tempest" that engages in its fury the other ergative agents of the "lightning" striking the "ship" that "went round and round" till all the seafarers fell into the sea.

The second extract presented to the two groups of migrants and tourists was drawn from Aeneid's Book III. Another stormy scene is represented, and again the tempest becomes a personification of an agent that relentlessly tries to destroy human beings:

Aeneid, III: verses 192-197 and their ethnopoetic ELF translation:

Postquam altum tenuere rates, nec iam amplius ullae

After the ship sailed, and the shores faded away,

adparent terrae, caelum undique et undique pontus,

and the sky was everywhere, and everywhere the sea,

tum mihi caeruleus supra caput adstitit imber,

on my head a burst of rain billowed

noctem hiememque ferens, et inhorruit unda tenebris.

loaded with tempest, black as night, and every wave grew dark and furious,

Continuo venti volvunt mare, magnaque surgunt

while ruffling winds upset the sea, and huge waves

aequora; dispersi iactamur gurgite vasto.

grew; we were lost hurled over the swirling sea.

Seafarers cross the sea with fear and anguish, and the monstrous natural phenomena suggest an identification between sea and death. The extract, indeed, is one of the most compelling instances of sea as a 'no return' (Lindenlauf, 2003), emphasizing the contrast between land and sea as opposing powers (Borca, 2002). This epic scene illustrates the sea as a relentless boiling force (Angelini, 2012, p. 55), as a cauldron, and the Messina Strait is represented as a dystopian place, a locus horridus in which the two worlds of humans and monsters are inextricably linked together through the personification of the Sirens as fatal bird-women enchanting sailors with their lethal chants, the Wandering rocks, Scylla, a semicanine maneating monster (Sole, 2000; Hopman, 2005) and the hidden ravenous Charybdis. The scene culminates in the storm that typically represents the transitus from life to death.

Also in this extract, the ethnopoetic translation of the original Latin verses into ELF is meant to update the ancient metrical forms of the hexameter typical of 
classical epic narrative, to the iambic pentameter that is closer to the rhythm of the modern journey narratives, and thus it is assumed to be more accessible to different groups of participants. Therefore, the objective of rendering Ancient-Greek and Latin narrative forms of classical 'lingua francas' into the contemporary rhythm of an ELF variation was to help them enquire into the possibility of adapting such epic narrative forms to migrants' everyday modes of communication (Lakoff \& Johnson, 1980, 1999; Guido, 2012). Finally, the participants were asked to focus on devising new, multimodal strategies of reproduction of ancient journey narratives to foster the creation of a shared emotional response on such dramatic experiences, as is now going to be described in the following section.

\section{Phase 3: Multimodal re-textualization of ELF narratives}

In the final phase of this research, the emphasis was on the development of multimodal strategies of representation of the interaction between the tragic images of migrants' actual journeys and the re-enactment of epic 'odysseys' in the corpus of ancient and modern sea-voyage narratives under investigation. The participants were involved in the definition of peculiar multimodal compositions (van Leeuwen, 2005) of audiovisual texts meant to reproduce, through an audiovisual mode, the frantic rhythms of such dreadful experiences. The video that is going to be analyzed§§ is one of the three texts that were the practical output of this pedagogical activity. A cognitive-functional (Langacker, 2008) and multimodal (van Leeuwen \& Jewitt, 2001) approach was applied to the creation of such audiovisual representations. This entails that the association between linguistic and extralinguistic "meaning-making resources" (Halliday, 1978) aims at conveying the producer's illocutionary intentions as well as monitoring the receivers' reactions to the perlocutionary effects of the video (Iaia, 2015). Precisely, the multimodal structure of the case study below is organized in such a way as to help the participants experience the similarities between ancient and contemporary dramatic sea-voyages, thus confirming the ultimate achievement of this research project, whereby the participants' 'personal growth' is pursued through their increased awareness of the shared emotional reaction to the dramatic events described here.

The video under examination portrays the tragic experiences of ancient and contemporary seafarers crossing the stormy sea. Under the guidance of the researcher, the participants selected those linguistic and extralinguistic elements whose combination realized the alternation of feelings that were conveyed by migrants and mythical voyagers. As for the visual dimension, a number of scenes from The History Channel's Odyssey and from online news videos about migrants trying to reach the Mediterranean coasts of Italy interact with images of a YouTube promotional video of Salento. The passage from mythical to actual odysseys is reflected by the nature of these visual items: when Odysseus' sea-voyage is

$\S \S$ The video was created by the author of this section, and can be watched at the following link: https://drive.google.com/open?id=0B8faW19SmcjeOGxjYjlxMnRzOHc. 
represented, the images are connoted as "narrative" illustrations, which represent "unfolding actions and events" (Kress \& van Leeuwen, 2006, p.59). Contemporary migrations, instead, are given the status of "generalized" and "timeless" events thanks to the inclusion of "conceptual" pictures (Kress and van Leeuwen, 2006, p.79). The passage from anticipation, anguish and terror is also marked by the musical score of a cinematic kind: the themes Point of no Return (in the first part - Table 1) and Epic Movie (second part - Table 2) have a regular rhythm that is reminiscent of an iambic verse, insofar as the musical score starts with a beat that, like a trochee, conveys the sense of a big thump in the seafarers' hearts caused by a sudden feeling of panic. Additionally, the combination of epic and actual sea-voyages is also reflected by the verbal features of the clip, which determine the captions underlying the association between the images of migrants' appalling voyages and the mythical 'odysseys'. In particular, the verbal dimension consists of a selected portion of Coleridge's The Rime of the Ancient Mariner and of the Nigerian migrant's ethnopoetic verse transcript that were the core of the pedagogical activity carried out in Phase 1 of this research as well as of the parts from Odyssey's Book XII and Aeneid's Book III (Phase 2). The video is divided into three parts: an introduction (00:00:00 - 00:00:06) which represents the moments just before the advent of the storm; the central part, with the shocking experience of migration (00:00:06 - 00:00:48); and the final section (00:00:48 00:01:04) characterizing Salento as a place of hope and relief. Such a connotation is suggested by watching the calm sea of Salento that appears right after Odysseus (identified as Ulysses in the multimodal analysis, as this was the name that the participants found more familiar in identifying the Homeric hero) and two migrant women who survived the storm anxiously looking back towards the sea. The captions drawn from the ELF transcriptions and renderings of the chosen extracts as well as the slogan that appears at the end of the short film are meant to become an essential semiotic dimension of the multimodal composition (Neves, 2009). More specifically, since they highlight the seafarers' emotional narrative of the tragic events that they have undergone, a specific font was adopted - the Brush Script MT - in order to represent such a report 'graphically', as it is evocative of handwritten notes on the sailors' diaries.

Table 1 below illustrates the multimodal composition of the first part of this advertisement: 
Table 1. Multimodal transcription of part one

\begin{tabular}{|c|c|c|c|c|}
\hline \multicolumn{3}{|c|}{ Image description } & \multicolumn{2}{|c|}{ Verbal caption } \\
\hline $\begin{array}{l}\text { Visual } \\
\text { frame }\end{array}$ & $\begin{array}{l}\text { Narrative } \\
\text { type }\end{array}$ & $\begin{array}{l}\text { Conceptual } \\
\text { type }\end{array}$ & $\begin{array}{c}\text { Epic } \\
\text { verses }\end{array}$ & $\begin{array}{c}\text { ELF } \\
\text { accounts }\end{array}$ \\
\hline & & $\begin{array}{l}\text { Migrants on a crowded } \\
\text { ship }\end{array}$ & & $\begin{array}{l}\text { An old ship } \\
\text { boarded us, } \\
\text { too many }\end{array}$ \\
\hline & & The migrants' ship teeters & & $\begin{array}{l}\text { The deck } \\
\text { was so } \\
\text { packed and } \\
\text { the hold so } \\
\text { crammed }\end{array}$ \\
\hline & $\begin{array}{l}\text { Cut to the lightning } \\
\text { illuminating the night sky }\end{array}$ & & $\begin{array}{l}\text { And now } \\
\text { the } \\
\text { 'STORM- } \\
\text { BLAST' } \\
\text { came }\end{array}$ & \\
\hline
\end{tabular}

The first part of the video stresses the dramatic and epic nature of the journey on an overcrowded ship: "too many" migrants are on the open sea and about to face the awful storm that is at the center of the second part. The abrupt appearance of the tempest is represented by the narrative illustration of a lightning illuminating the night sky and by the caption with a line from Coleridge's verse in the middle of the visual frame, whereas the music passes from a calm to a rhythmic soundtrack. The sudden movement from narrative to conceptual patterns, along with the fast cinematic pace and dramatic soundtrack convey the traumatic experience represented in such ancient and contemporary 'odysseys', but are also meant to attract the viewers' attention. From this perspective, addressees are expected to be captivated by the 'arousal/safety' emotional pattern built on the blend of modern and mythical seavoyages, and on the alternation between the migrants' oral narratives and Coleridge's lines. At the end of the clip, the final promotional slogan appears, introducing an anticlimax.

In parts two and three, Odysseus and his companions fearlessly struggle against the storm and the rough sea that cause the shipwreck. The multimodal composition of these parts is reported in Table 2 below: 
Table 2. Multimodal transcription of parts two and three

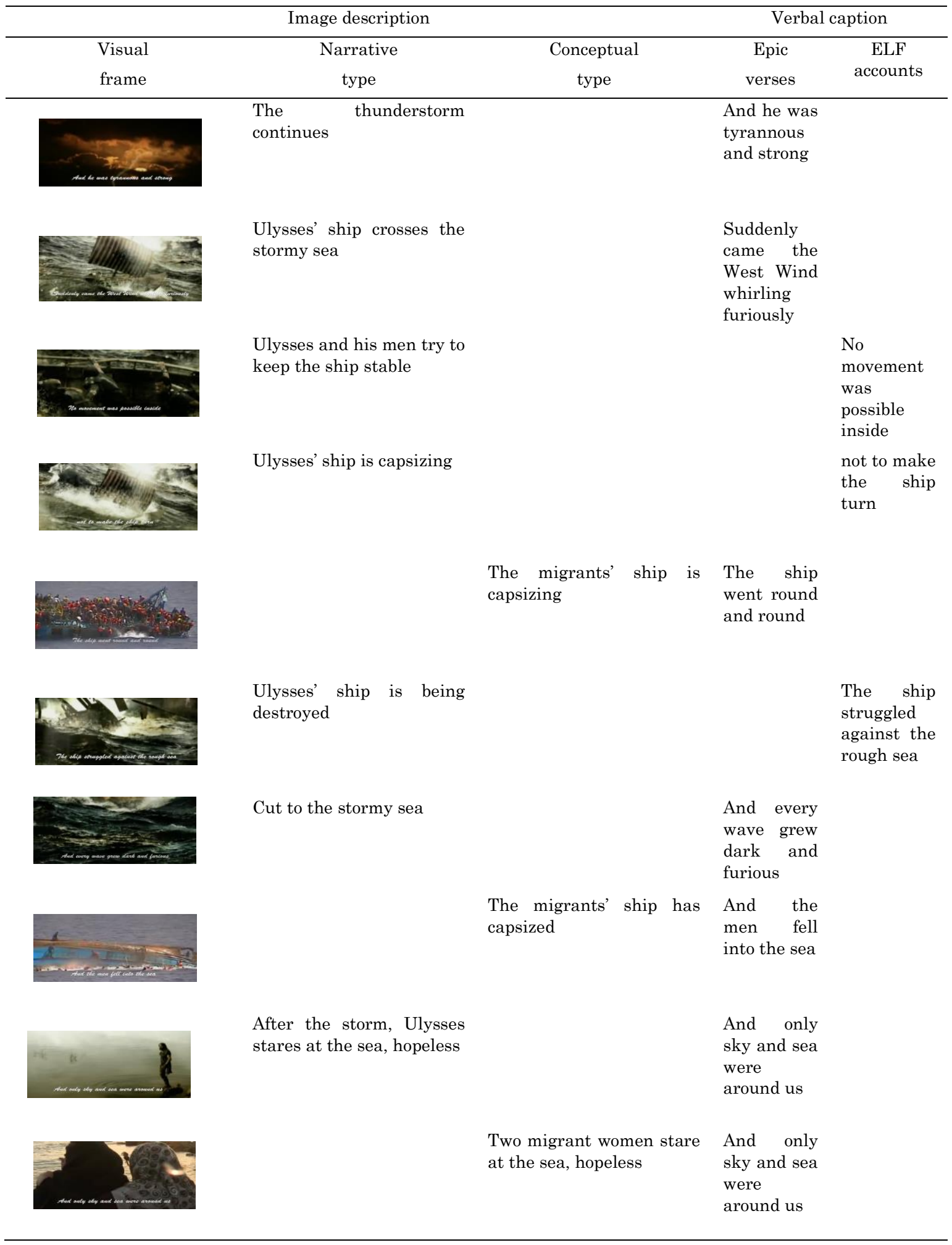

The fast and rapid visual switch from mythical to actual 'odysseys' reproduces the speedy rhythm of the original ethnopoetic narratives and reflects the mounting agony 
and terror in seafarers. In the final segment, instead, the multimodal construction was devised so as to associate the Salento's sea with the way to a safe haven, with the mythical Utopia which triggers the feeling of hope and relief in travelers. The 'fade out to white' effect that closes the second part and opens the third one, along with a more relaxing soundtrack, emphasize such associations, thus implicating the end of a nightmare. Indeed, the real sound of the sea evokes the end of a perilous quest with the arrival at a safe harbor, as underlined by the slogan "SALENTO - Look back in relief", which introduces a cultural reference to John Osborne's play Look back in anger. This multimodal composition eventually induces the receivers' emotionally positive response to the effects of the video upon them.

\section{Conclusions}

This paper has reported on an ongoing experiential-linguistics research project in Responsible Tourism involving students of intercultural mediation at the University of Salento, intercultural mediators, tourists, migrants and local communities. The project combines cultural activities of ethnopoetic analysis of migrants' ELF seavoyage narrative and ancient tales, the ELF translation of epic accounts of migrations, as well as the production of multimodal videos. By disclosing the structural and rhythmical similarities between the ancient epic and the modern oral sea-voyage reports reorganized through ELF into ethnopoetic verses, the ultimate objective of this research project is to guide the participants to become aware of the fact that they share the same cultural roots as seafaring people, thus fostering intercultural cooperation and integration between non-Western and Western people living in seaside resorts affected by migrants' mass arrivals.

\section{References}

Anderson, T. (1988). Ergativity in Pari, a Nilotic OVS Language. Lingua, 75(4), 283-324. https://doi.org/10.1016/0024-3841(88)90008-3

Angelini, A. (2012). Spazio marino e metafore della morte nel mondo antico. In F. Marzari (Ed.), Per un atlante antropologico della mitologia greca e romana (pp. 49-62). Siena: I Quaderni Del Ramo D'oro On-Line.

Borca, F. (2002). In orbem intrare: l'Oceano, il Mediterraneo e le Colonne d'Ercole. In M. Khanoussi, P. Ruggeri, \& C. Vismara (Eds.), Atti del XIV Convegno Internazionale di Studi 'L'Africa romana' (pp. 123-128). Rome: Carocci.

Buth, R. J. (1981). Ergative Word Order - Luwo is OVS. Occasional Papers in the Study of Sudanese Languages, 1, 74-90.

Carrell, P. L. (1983). Some issues in the role of schemata, or background knowledge, in second language comprehension. Reading in a Foreign Language, 1(2), 81-92.

De Jong, I. J. F. (2001). A Narratological Commentary on the Odyssey. Cambridge: Cambridge University Press. https://doi.org/10.1017/CBO9780511482137

Eze, E. (1998). Lending Credence to a Borrowing Analysis: Lone English-Origin Incorporations in Igbo Discourse. International Journal of Bilingualism, 2(2), 183-201.

Greenberg, J. H. (1963). The Languages of Africa. The Hague: Mouton. 
Guido, M. G. (1999). The Acting Reader: Schema/Text Interaction in the Dramatic Discourse of Poetry. New York / Toronto / Ottawa: Legas.

Guido, M. G. (2008). English as a Lingua Franca in Cross-cultural Immigration Domains. Bern: Peter Lang. https://doi.org/10.3726/978-3-0351-0664-0

Guido, M. G. (2012). ELF authentication and accommodation strategies in cross-cultural immigration domain. Journal of English as a Lingua Franca, 1(2), 219-240. https://doi.org/10.1515/jelf-2012-0017

Guido, M. G. (2016). ELF in responsible tourism: A case study on unequal migration encounters. In M. L. Pitzl \& R. Osimk-Teasdale (Eds.), ELF Perspectives and Prospects (pp. 49-56). Berlin: De Gruyter Mouton.

Guido, M. G. (2018). English as a Lingua Franca in Migrants' Trauma Narratives. London: Palgrave Macmillan. https://doi.org/10.1057/978-1-137-58300-0

Guido, M. G., Errico, L., Iaia, P. L., \& Amatulli, C. (2016). ELF narratives of ancient and modern 'odysseys' across the Mediterranean Sea: An Experiential-Linguistic Approach to the marketing of Responsible Tourism. Cultus: The Journal of Intercultural Mediation and Communication, 9(1), 90-116.

Guido, M.G., Iaia, P. L., \& Errico, L. (2018). ELF-mediated intercultural communication between migrants and tourists in an Italian project of Responsible Tourism: A multimodal ethnopoetic approach to modern and classical sea-voyage narratives. In I. Guillén-Galve \& I. Vázquez-Orta (Eds.), English as a Lingua Franca and Intercultural Communication. Implications and Applications in the Field of English Language Teaching (pp. 97-123). Bern: Peter Lang.

Halliday, M. A. K. (1978). Language as Social Semiotic: The Social Interpretation of Language and Meaning. London: Edward Arnold.

Halliday, M. A. K. (1994) An Introduction to Functional Grammar. London: Edward Arnold.

Heine, B., \& Nurse, D. (2000). African Languages: An Introduction. Cambridge: Cambridge University Press.

Hopman, M. I. (2005). The maiden of the straits. Scylla in the cultural poetics of Greece and Rome. Unpublished doctoral dissertation. Harvard University, Harvard.

Hosany, S., \& Prayag, G. (2011). Patterns of tourists' emotional responses, satisfaction, and intention to recommend. Journal of Business Research, 66(6), 730-737. https://doi.org/10.1016/j.jbusres.2011.09.011

Hymes, D. (2003). Now I Know Only So Far: Essays in Ethnopoetics. Lincoln: University of Nebraska Press.

Iaia, P. L. (2015). The Dubbing Translation of Humorous Audiovisual Texts. Newcastle upon Tyne: Cambridge Scholars Publishing.

Kress, G. (2009). Multimodality: A Social Semiotic Approach to Contemporary Communication. London: Routledge. https://doi.org/10.4324/9780203970034

Kress, G., \& van Leeuwen, T. (2006). Reading Images: The Grammar of Visual Design. London: Routledge. https://doi.org/10.4324/9780203619728

Lakoff, G., \& Johnson, M. (1980). Metaphors We Live By. Chicago, IL: University of Chicago press.

Lakoff, G., \& Johnson, M. (1999). Philosophy in the Flesh: The Embodied Mind and its Challenge to Western Thought. New York: Basic Books.

Langacker, R. W. (1991). Foundations of Cognitive Grammar. Volume II: Descriptive Application. Stanford: Stanford University Press.

Langacker, R. W. (2008). Cognitive Grammar. A Basic Introduction. Oxford: Oxford University Press. https://doi.org/10.1093/acprof:oso/9780195331967.001.0001 
Lin, Y., Kerstetter, D., Nawijin, J., \& Mitas, O. (2014). Changes in emotions and their interactions with personality in a vacation context. Tourism Management, 40, 416-424. https://doi.org/10.1016/j.tourman.2013.07.013

Lindenlauf, A. (2003). The sea as a place of no return in Ancient Greece. World Archaelogy, 35(3), 416-433. https://doi.org/10.1080/0043824042000185801

Ma, J., Gao, J., Scott, N., \& Ding, P. (2013). Customer delight from theme park experiences: The antecedents of delight based on Cognitive Appraisal Theory. Annals of Tourism Research, 42, 359-381. https://doi.org/10.1016/j.annals.2013.02.018

Mondarini, G. (2005). Le acque del mare come luogo del limen: riflessioni intorno alla leggenda di Cola Pesce. La ricerca folklorica, 51, 75-83. https://doi.org/10.2307/30033275

Moulinier, L. (1958). Quelques hypothèses relatives à la géographie d'Homère dans l'Odyssée. Aix-en-Provence: Publ. des annales de la faculté des lettres.

Neves, J. (2009). Interlingual subtitling for the deaf and hard-of-hearing. In J. Díaz Cintas \& G. Anderman (Eds.), Audiovisual Translation: Language Transfer on Screen (pp. 151-169). Basingstoke: Palgrave Macmillan. https://doi.org/10.1057/9780230234581 12

Prayag, G., Hosany, S., \& Odeh, K. (2013). The role of tourists' emotional experiences and satisfaction in understanding behavioural intentions. Journal of Destination Marketing \& Management, 2(2), 118-127. https://doi.org/10.1016/j.jdmm.2013.05.001

Sole, G. (2000). Scilla. Interpretazioni di un mito. Rende: Centro Editoriale e Librario Università della Calabria.

Sweetser, E. E. (1990). From Etymology to Pragmatics: Metaphorical and Cultural Aspects of Semantic Structure. Cambridge: Cambridge University Press. https://doi.org/10.1017/CBO9780511620904

Talmy, L. (1988). Force dynamics in language and cognition. Cognitive Science, 12(1), 49-100. https://doi.org/10.1207/s15516709cog1201_2

van Leeuwen, T. (2005). Introducing Social Semiotics. London: Routledge. https://doi.org/10.4324/9780203647028

van Leeuwen, T., \& Jewitt, C. (2001). Handbook of Visual Analysis. London: Sage.

\section{Copyrights}

Copyright for this article is retained by the author(s), with first publication rights granted to the Journal.

This is an open-access article distributed under the terms and conditions of the Creative Commons Attribution license (CC BY-NC-ND) (http://creativecommons.org/licenses/by-nc-nd/4.0/). 